\title{
Cal Poly's Response to the AIDS Crisis of the 1980s
}

By Tessa St. Clair

"It would probably bother me because it's such a social disease." ${ }^{1}$ So responded a student of California Polytechnic State University San Luis Obispo when asked if she would be bothered if a classmate had AIDS for a 1986 article in The Mustang Daily. Referring to AIDS as a "social disease," as opposed to a sexually transmitted disease, reflected the common misconception at the time that AIDS could be contracted by casual contact with someone who had it. Many misconceptions arose after the first cases of AIDS, otherwise known as Acquired Immune Deficiency Syndrome and later known as HIV in its first stages, were reported in June of $1981 .^{2}$ Little did the world know that in the following years to come, the number of lives taken by the mysterious disease would total an estimated 34 million as of 2014. ${ }^{3}$ Those affected by the virus were of all ethnicities, genders, and even ages: college students and elderly alike.

College campuses were infamously known as institutions full of young and sexually active individuals. Sexually transmitted diseases were considered commonplace at such institutions; however, the outbreak of AIDS and the subsequent years in which research brought new information to light was unlike anything campuses had seen before, and it was for this purpose a closer look at the reactions of $\mathrm{Cal}$ Poly students and administration was important. How did Cal Poly respond to the crisis? Did they take extra measures to educate students about AIDS? How did the students themselves feel about the

1 Holly Johnson, "Would it Bother you if a Classmate had AIDS?" The Mustang Daily, October 1, 1986, accessed February 28, 2016, http://goo.gl/Gv7Vez, 2.

2 United States Department of Health and Human Services: AIDS, “A Timeline of HIV/AIDS" 2015, accessed February 28, 2016, http://www.aids.gov/hiv-aids-basics/hiv-aids-101/aids-timeline/ .

3 United States Department of Health and Human Services: AIDS, "Global Statistics" 2015, accessed February 28, 2016, https:/www.aids.gov/hiv-aids-basics/hiv-aids-101/global-statistics/. 
growing epidemic? Did they subscribe to common misconceptions, such as accusations towards the homosexual community?

To answer these questions, this paper will examine several articles from $\mathrm{Cal}$ Poly's newspaper The Mustang Daily published in the 1980s. The '80s were the formative years in which the world became increasingly aware of how exactly HIV/AIDS affected the body, how it was transmitted, and what people could do to prevent its spreading. I will use sources that gauge public opinion to examine Cal Poly student responses to the outbreak of AIDS. In addition, this paper will use secondary sources to contrast and compare the responses of other universities to that of Cal Poly. This paper will provide insight into how Cal Poly, a traditionally conservative campus, dealt with the crisis from both the perspective of the administration and student body. While Cal Poly welcomed open discussion about AIDS and made it a priority to inform students of risks, it struggled to provide resources and avoid taboos.

\section{Historiography}

Scholars and health officials alike have extensively researched the AIDS crisis and popular reactions to it; however, student opinions and AIDS prevention on college campuses were less explored. Many sources on this topic are from the first century, after AIDS was first discovered, and signify the increased need to enforce prevention on campus. In an article titled "The AIDS Crisis: Intervention and Prevention," Dr. Vivian B. Brown proclaimed that "the most important goals for colleges and institutions are increasing awareness and providing education" to combat the spread of AIDS. ${ }^{4}$ Awareness and education to Cal Poly meant holding as many informational events as possible. Yet, the university held back from direct action such as providing condom dispensers. One study focusing on historically black colleges and universities proposed that the "most salient barriers to safe sex practices were negative views of con-

4 Vivian B. Brown, "The AIDS Crisis: Intervention and Prevention," New Directions for Student Services 1990.49, accessed February 28, 2016, http://dx.doi.org/10.1002/ss.37119904908, 67. 
doms, trust issues and spontaneity." This idea proved to be true at Cal Poly; students' opinions on safe sex impacted their choices. Students longed to push past the perception of sex as secretive and make condoms readily available.

Years passed before Cal Poly stopped talking about AIDS and acted. The university mirrored the chaos and struggle of the entire country in the 1980s. In Randy Shilts' investigative novel, And the Band Played On, he expressed extreme disappointment in the handling of the AIDS crisis. He contended that "nearly five years passed before all these institutions-medicine, public health, the federal and private scientific research establishments, the mass media, and the gay community's leadership-mobilized the way they should in a time of threat." "Shilts' condemnation of the country's disorganization suggests that although Cal Poly should have done better, they at least educated students in a world where President Reagan did not even acknowledge AIDS until five years passed. ${ }^{7}$ Instances where students, as well as administrators, spoke candidly about AIDS awareness revealed how Cal Poly sought to make changes in the wake of a serious outbreak, which in turn gave insight into the worldwide panic prevalent in the decades following the discovery of AIDS.

\section{The Students}

Looking at student opinion during the AIDS crisis was vital to understanding Cal Poly's reactions. The Mustang Daily was a student-run newspaper, which made what they chose to print about AIDS a reflection of student attitudes towards it. Several articles published during the crisis gauged the opinions of students toward the issues surrounding AIDS. In fact, one passionate student wrote to the editors thanking the paper for "having the courage to print a

5 Maurice Y. Mongkuo et al, "Perception of HIV/AIDS and Socio-Cognitive Determinants of Safe Sex Practices Among College Students Attending a Historically Black College and University in the United States of America," Journal of AIDS and HIV Research 2 no. 3 (2010): 34, accessed February 28, 2016, http://goo. gl/0Lwen 1 .

6 Randy Shilts, And The Band Played On: Politics, People, and the AIDS Epidemic (New York:

St. Martin's Press, 1987), 44.

7 Ibid. 
featured article on AIDS." ${ }^{8}$ The article that the student referred to was an informative article published a few days prior that explained what AIDS was and dispelled several myths about the disease. It included a chart detailing the symptoms and precautions students could take to avoid contracting AIDS. ${ }^{9}$ The student's statement showed that it took courage to talk so openly about AIDS, even after three years had passed since its initial outbreak. Cal Poly remained outspoken through the student newspaper by publishing prevention methods and informing students of risks and precautions.

$\mathrm{Cal}$ Poly literature revealed major discrepancies when it came to various reports on the level of seriousness with which students perceived AIDS. On one hand, there were several instances when faculty and students themselves maintained an unconcerned attitude towards the virus. A representative for the AIDS foundation in San Francisco, in The Mustang Daily, stated that "the biggest problem with college students is they do not see AIDS as a young persons disease." ${ }^{10}$ In many cases, the same seems to be true for Cal Poly students. In a 1985 article, only two out of six students responded "yes" to the question "are you concerned about the disease AIDS or are you afraid of catching it?"11 Yet other publications seemed to tell the opposite story, in some cases within the same article. In an article that interviewed the president of the Cal Poly Gay and Lesbian Student Union (GLSU), he stated that AIDS has strongly impacted his friend group, who consequently decided to cut back on risky behavior since AIDS' spread. Yet the advisor of the GLSU said sentences later that "gay male [Cal Poly] students tend to ignore the issue of AIDS." 12

8 Scott Miller, "Story About AIDS Commended by Reader," The Mustang Daily, October 29, 1985, accessed February 28, 2016, http://goo.gl/QNTqny, 2.

9 Renee Shupe, “A 'Terrifying' Disease: AIDS and its Many Victims," The Mustang Daily, October 24, 1985, accessed February 28, 2016, http://goo.gl/jgZdZM, 5.

10 Renee Shupe, "AIDS: Deadly Disease Threatens More Than Homosexuals," The Mustang Daily, October 24, 1985, accessed February 28, 2016, http://goo.gl/jgZdZM, 1.

11 Kevin Cannon and Renee Shupe, "Are you Concerned About the Disease AIDS or are you Afraid of Catching It?” The Mustang Daily, October 24, 1985, accessed February 28, 2016, http://goo.gl/jgZdZM, 2.

12 Dawn Yoshitake, “AIDS: A Disease Carrying Common Misconceptions," The Mustang Daily, April 12, 1985, accessed February 28, 2016, http://goo.gl/SNGsSU, 6. 
The same contradiction arose in a piece focusing on STDs at Cal Poly, when the Director of the Cal Poly Health Center, Dr. James Nash, voiced concerns that students on campus tend to have an "it would never happen to me" mentality and should be more concerned with the rise and spread of AIDS; however, a fellow health professor followed his statement by saying that she found Cal Poly students seemed very concerned as she got several students worried about AIDS coming into the health center each week. ${ }^{13}$ One possible explanation for the conflicting reports of student concern was that students believed the cure was just on the horizon. As one student explained in a letter to the editor in 1984, "the cure for AIDS is almost here." ${ }^{14}$ Cal Poly faculty, like Dr. Nash over-exaggerating students' lack of concern, was another equally valid possibility. Although the question cannot be sufficiently answered, it was clear that students' concern, or lack thereof, was not due to a lack of knowledge of the virus.

By far one of the biggest misconceptions perpetuated during the years following the AIDS outbreak was that the disease was caused by or exclusively transmitted through homosexual men. This misconception lead to many negative reactions and general mistrust or hostility towards homosexual men. Articles and editorials featured in The Mustang Daily did not shy away from conversations on this topic, and further analysis revealed that gay youth on Cal Poly's campus were adversely affected by the AIDS crisis. Miller, the same student who thanked the paper for their candid pieces on AIDS, recalled a woman telling him that gay people "got what they deserve." ${ }^{15}$ This woman was alluding to a theory circulating at the time that AIDS was God's way of punishing and removing homosexual men from the Earth. Although Miller did not directly implicate Cal Poly, the student did express that he felt strong negativity directed towards homosexual men on campus. Other students,

13 Catherine Hernandez, "The Fear of Getting Close," The Mustang Daily, March 4, 1987, accessed February 28,2016 , http://goo.gl/tXfSEQ, 5 .

14 'A concerned student', "People Urged to Recognize Alternative, Gay Lifestyles," The Mustang Daily, November 7, 1984, accessed February 28, 2016, http://goo.gl/C7W1D4, 2.

15 Miller, "Story About AIDS Commended by Reader," 2. 
however, were more explicit in pointing a finger at Cal Poly. One such student writing to the editor expressed that they had read and heard "derisive comments about gays at Cal Poly," in part due to the stigma surrounding AIDS and the belief that it would "cure the world of gays." ${ }^{16}$ These instances were not the only ones indicating that Cal Poly was affected by social stigma surrounding AIDS. Gene Calgari, the president of the GLSU, shared similar insight in an article focused on the growing anti-gay attitude at Cal Poly. Caligari stated that he had observed anti-gay sentiment on campus and that he believed that such sentiment was preventing closeted students from coming out. ${ }^{17} \mathrm{~A}$ fellow member of the GLSU stated on another occasion that she highly doubted any gay students who suspected they could be infected would go to the campus health center due to the stigma surrounding AIDS. ${ }^{18}$ As given in these testimonies, many students acknowledged that they felt marginalized or discriminated against because of the opprobrium of their fellow students; however, the fact that the paper chose to include the testimonies at all and allowed students to openly discuss the issue demonstrates the willingness of Cal Poly to address AIDS and peoples' thoughts on the virus.

\section{The Administration}

The student's opinions gave insight into how the student body dealt with the stigma and common misconceptions associated with the topic of AIDS. To further understand the reaction of Cal Poly as a whole, an analysis of the administration's responses to AIDS is also necessary. It was, after all, campus administration's responsibility to decide how to deal with the growing epidemic. When it came to education and awareness of AIDS, administration prevailed in creating open discussions. The Mustang Daily published several stories on AIDS, which signified that Cal Poly's administration allowed such discussion to be presented to students.

16 'A concerned student', "People Urged to Recognize Alternative, Gay Lifestyles," 2.

17 Jerry McKay, "Anti-gay Attitude Increasing," The Mustang Daily, January 22, 1987, accessed February

28, 2016, http://goo.gl/OyCgb9, 4.

18 Yoshitake, "AIDS," 4. 
The administration went beyond simply allowing the paper freedom of press; they also invited guest speakers to speak about AIDS, held conferences aimed at educating the student body, and teamed up with local organizations to keep students well-informed. For example, Richard Siegel, a genetics professor at UCLA, came to Cal Poly in 1987 and gave an informative talk about AIDS.19 In similar fashion, Richard Keeling of the American College Health Association, visited Cal Poly during a two-day awareness event. Keeling warned that AIDS' spread to college campuses was imminent and that statistically "about 45 to 50 Cal Poly students [should] have the virus.”20 Keeling's warning cry of an increase in AIDS cases at Cal Poly was not unique, but rather echoed others who made the same prediction. In an informational meeting similar to several events held at Cal Poly in the 1980s, administration worked in coordination with the AIDS project coordinator for the tri-counties. The event sought to "provoke community discussion" about AIDS. 21 Additional effort was made by Cal Poly's health center; it teamed up with the San Luis Obispo County AIDS task force to provide assistance in the form of an AIDS support group created to help both AIDS patients and those who had lost loved ones to the disease.22 Cal Poly showed students not only their willingness to provide counseling services to loved ones, but also support for local efforts to educate the community. While administration provided many events and informational talks, these events were optional. More permanent methods of education included a huge push by Cal Poly professors to more adequately educate students on AIDS and prevention techniques in 1987. They vowed to begin lecturing on AIDS extensively in health courses and include textbooks that provided AIDS information.23 The addition of AIDS to the curriculum

19 Carol J. Vance, “AIDS: The Modern Plague,”The Mustang Daily, May 8, 1984, accessed February 28, 2016, http://goo.gl/yU9150, 1.

20 Mark Ahlemeyer, "Universities Must Face Reality of AIDS Crisis, Says Expert,"The Mustang Daily, April 6, 1989, accessed February 28, 2016, http://goo.gl/T6bY16, 1.

21 “AIDS Conference Slated for June as SV Hospital," The Mustang Daily, May 18, 1985, accessed February 28, 2016, http://goo.gl/zORo1L, 2.

22 Yoshitake, "AIDS: A Disease Carrying Common Misconceptions," 6.

23 Carol J. Vance, "AIDS to be Part of Books, Classes," The Mustang Daily, April 9, 1987, accessed February 28, 2016, http://goo.gl/sYHPYj, 3. 
affirmed that the campus was making a legitimate effort to keep their students informed.

Cal Poly was very successful at informing students about AIDS by providing all of the necessary tools to learn more. However, when it came to going beyond words and taking action, Cal Poly lacked in taking stronger measures. For example, although Cal Poly repetitively encouraged the use of protection, the ongoing debate over providing contraceptives failed due to administrations inability to look past taboos rooted in ignorance. In 1987, the Student Senate made an effort to place condom dispensers in campus restrooms. ${ }^{24}$ The resolution passed, only to be vetoed by ASI president Kevin Swanson, who illogically insisted that readily available condoms would promote promiscuity and abortion rates and that "education is the only real solution for the epidemic." ${ }^{25}$ Therefore, the taboo of sex as strictly private and protection as promiscuous trumped proactive action to help prevent AIDS.

Furthermore, a second motion included in the Student Senate's proposal that brought increased AIDS and STD awareness passed; this showed that administration backed AIDS awareness, but would not take one step beyond this symbolic stance by adding condom dispensers. ${ }^{26}$ The movement to add condoms to the restrooms provoked numerous responses from students in the subsequent editorials. One student, Debbie Johnson, fully supported the veto of the Student Senate's proposal, remarking that "condoms are available at health centers and drug stores and it should stay that way. ${ }^{27}$ Her remarks sparked two passionate responses from students, Elise Stewart and Laura Robinson, who both wrote in to the editor the following week. ${ }^{28}$ They both argued against Johnson's ideas; Stewart added that "[condoms] are a means

24 Kim Holweger, "Student Senate OKs Condoms in Poly Restrooms," The Mustang Daily, May 22, 1987, accessed February 28, 2016, http://goo.gl/pT3PJ5, 1.

25 Kim Holweger, “S. Senate Can’t Override Condom Dispenser Veto," The Mustang Daily, May 29, 1987, accessed February 28, 2016, http://goo.gl/P1bDte, 1.

26 Ibid., 1.

27 Debbie Johnson, "Wall Mounting not the Answer," The Mustang Daily, October 29, 1987, accessed February 28, 2016, http://goo.gl/wCvoCx, 2.

28 Laura Robinson, “Condoms cont.," The Mustang Daily, November 3, 1987, accessed February 28, 2016. http://goo.gl/9mCimw, 2. 
to save your life...until the cure for AIDS is found." ${ }^{29}$ The student's mixed responses showed that although many students demonstrated more progressive attitudes towards prevention, some stood by Cal Poly's conservatism. The fear of promoting promiscuity, or of being seen as doing so, became one of the major setbacks that persuaded administration away from taking firm action.

\section{A Comparison with San Francisco State University}

AIDS was a commonly explored subject because of its massive effect on the world. The disease came unexpectedly and was shrouded in mystery during the first years of its discovery; it went from a nameless illness, to a widely known and feared plague. Due to its sudden nature, Cal Poly, along with all college campuses, had no existing plan for the occurrence of a global outbreak. In 1985, three years after AIDS was given a name and its symptoms became known, Cal Poly still had no plan in place specifying any regulations in relations to AIDS. At this time, the school was merely following the instructions of the CDC. ${ }^{30}$ In a 1985 article, Dr. Nash argued that any Cal Poly student that might become infected should be allowed to remain on campus. ${ }^{31}$ That same year, San Francisco State University, a fellow CSU, already created an AIDS task force aimed at educating students of the virus; it also established a non-discrimination policy meant to protect HIV positive students. The task force was the "first committee to address HIV/AIDS on campuses in the nation [and] the first non-discrimination policy in the nation [for AIDS patients]. ${ }^{32}$ When it came to AIDS prevention and acting quickly, San Francisco State was much more progressive in their reaction than Cal Poly was.

Some may argue that SFSU's haste in acquiring AIDS programs can be explained by the fact that AIDS was more prevalent there; however, San Francisco had a much denser population than San Luis Obispo and it is incorrect

29 Elise Stewart, "The Restroom is for Condoms," The Mustang Daily, November 3, 1987, accessed February 28,2016 , http://goo.gl/9mCimw, 2.

30 Shupe, "AIDS: Deadly Disease Threatens More Than Homosexuals," 1.

31 Ibid., 1.

32 Avery Peterson, “Timeline: The History of SF's Fight Against AIDS," Golden Gate Express, April 14, 2015, accessed February 28, 2016, http://goldengatexpress.org/2015/04/14/aids-awareness-day-1985/. 
to assume that San Luis Obispo was untouched by AIDS. In 1986 there was twelve known cases of AIDS in San Luis Obispo county. ${ }^{33}$ By 1989, that number had nearly tripled to 34 known cases. ${ }^{34}$ These figures only include reported cases, which disregards the number of cases where individuals either did not wish to publicize their status, or were not even aware that they were infected. Cal Poly did not establish a non-discrimination policy, as Dr. Nash had fought for, until the following year in 1986. The policy was not put into place by Cal Poly itself, rather by a campus-wide mandate for all California State Universities. ${ }^{35}$

\section{Overview of Cal Poly}

The articles produced by The Mustang Daily opened up several discussions about AIDS and revealed how students' opinions of the crisis affected them. The administration's words and actions also gave insight into the management during an epidemic. Cal Poly did fall victim to certain taboos encompassing the AIDS virus. Homosexual men at Cal were deeply affected by taboos; as a group, they especially felt the strain of judgment transferred from the epidemic to their select group of people. At this time, sex was seen as taboo, and the promotion of condoms was seen as promoting promiscuity (mainly by the fault of administration). In spite of seemingly unavoidable taboos for Cal Poly, it made a superior effort to always keep students well-educated about the disease through the various different events, both local and campus based, which students were invited to. The mixed consensus of students, either terrified of AIDS or unaffected by any paranoia, showed that students were indeed thinking critically about the crisis during its development. What distinguished Cal Poly from other universities like San Francisco State was their hesitation to put into play actual policies or provide more mobilized support to help students.

33 Shupe, "AIDS: Deadly Disease Threatens More Than Homosexuals," 1.

34 San Luis Obispo County Public Health Department AIDS Program, "Epidemiological Profile HIV/AIDS in San Luis Obispo County, CA," June 2007, accessed February 28, 2016, http:/goo.gl/G6XHkU.

35 Peterson, "Timeline." 
A look at Cal Poly at the present revealed that the university changed dramatically. During Cal Poly's "Week of Welcome," new students attend talks that include information on safe sex practices. Students are made aware of the resources, like the health center, which sell condoms and Plan B contraceptives at a low cost. ${ }^{36}$ PULSE, a peer health education team on campus, has a branch called EROS. EROS is entirely dedicated to "best guide you with birth control choices and relevant safe-sex practices, inform you about sexually transmitted infections (STIs), and direct [students] to make healthy decisions about sex. ${ }^{37}$ Condoms are also sold at on-campus stores such as Campus Market. Cal Poly's Pride Center acts as a safe space for the LGBTQ community and provides counseling services. ${ }^{38}$ In addition to these options, the health center has a link on their website directing students to where they can get more information on AIDS/HIV, including where they can be anonymously tested, or for those already diagnosed, where they can seek counseling. ${ }^{39}$ Availability and education have increased, in large part due to the conversation the AIDS crisis started on safe sex and the role of the campus in prevention.

36 California Polytechnic University San Luis Obispo, "Plan B- Emergency Contraception," Campus Health and Wellbeing, accessed March 13, 2016, http://www.hcs.calpoly.edu/content/health/planb.

37 California Polytechnic University San Luis Obispo, "Educational Resources on Sexuality," Campus Health and Wellbeing, accessed March 13, 2016, http:/hcs.calpoly.edu/pulse/students/teams/EROS.

38 California Polytechnic University San Luis Obispo, "Pride Center," Dean of Students, accessed March 13, 2016, http://www.deanofstudents.calpoly.edu/content/pride/index.

39 California Polytechnic University San Luis Obispo, "AIDS/HIV Information," Campus Health and Wellbeing, accessed March 13, 2016, http://hcs.calpoly.edu/content/health/aidshiv. 
'A concerned student'. "People Urged to Recognize Alternative, Gay Lifestyles." The Mustang Daily. California Polytechnic State University. November 7, 1984. Accessed February 28, 2016. http://goo.g1/C7W1D4.

Ahlemeyer, Mark. "Universities Must Face Reality of AIDS Crisis, Says Expert." The Mustang Daily. California Polytechnic State University. April 6, 1989. Accessed February 28, 2016. http://goo.gl/T6bY16.

"AIDS Conference Slated for June as SV Hospital." The Mustang Daily. California Polytechnic State University. May 18, 1984. Accessed February 28, 2016. http://goo.g1/zORo1L.

Brown, Vivian B. "The AIDS Crisis: Intervention and Prevention." New Directions for Student Services 1990.49 (Spring 1990): 67-74. Accessed February 28, 2016. http://dx.doi.org/10.1002/ss.37119904908.

California Polytechnic University San Luis Obispo. "AIDS/HIV Information.” Campus Health and Wellbeing. Accessed March 13, 2016. http://hcs.calpoly.edu/ content/health/aidshiv.

. "Educational Resources on Sexuality." Campus Health and Wellbeing. Accessed March 13, 2016. http://hcs.calpoly.edu/pulse/students/teams/EROS. . "Plan B- Emergency Contraception." Campus Health and Wellbeing. Accessed March 13, 2016. http://www.hcs.calpoly.edu/content/health/planb. . "Pride Center." Dean of Students. Accessed March 13, 2016. http://www. deanofstudents.calpoly.edu/content/pride/index.

Cannon, Kevin and Shupe, Renee. "Are you Concerned About the Disease AIDS or are you Afraid of Catching It?” The Mustang Daily. California Polytechnic State University. October 24, 1985. Accessed February 28, 2016. http://goo.g1/jgZdZM.

Hernandez, Catherine. "The Fear of Getting Close." The Mustang Daily. California Polytechnic State University. March 4, 1987. Accessed February 28, 2016.http:// goo.g1/tXfSEQ. 
Holweger, Kim. “S. Senate Can't Override Condom Dispenser Veto.” The Mustang Daily. California Polytechnic State University. May 29, 1987.

Accessed February 28, 2016. http://goo.g1/P1bDte.

. "Student Senate OKs Condoms in Poly Restrooms." The Mustang Daily.

California Polytechnic State University. May 22, 1987. Accessed February 28, 2016. http://goo.gl/pT3PJ5.

Johnson, Debbie. "Wall Mounting not the Answer." The Mustang Daily. California

Polytechnic State University. October 29, 1987. Accessed February 28, 2016. http://goo.gl/wCvoCx.

Johnson, Holly. "Would it Bother you if a Classmate had AIDS?" The Mustang Daily.

California Polytechnic State University. October 1, 1986. Accessed February 28, 2016. http://goo.gl/Gv7Vez.

McKay, Jerry. “Anti-gay Attitude Increasing.” The Mustang Daily. California

Polytechnic State University. January 22, 1987. Accessed February 28, 2016. http://goo.gl/OyCgb9.

Miller, Scott. "Story About AIDS Commended by Reader." The Mustang Daily.

California Polytechnic State University. October 29, 1985. Accessed February 28, 2016. http://goo.gl/QNTqny.

Mongkuo, Maurice Y., Mushi, Richard J., and Thomas, Rollinda. "Perception of HIV/AIDS and Socio-Cognitive Determinants of Safe Sex Practices Among College Students Attending a Historically Black College and University in the United States of America.” Journal of AIDS and HIV Research 2.3 (2010): 34. Accessed February 28, 2016. http://goo.gl/0Lwcn1.

Peterson, Avery. "Timeline: The history of SF State's fight against AIDS.” Golden Gate Express. April 14, 2015. Accessed March 10, 2016.http://goldengatexpress org/2015/04/14/aids-awareness-day-1985/. 
Ramsum, Darlene L., Stephen A. Marion, and Richard G. Mathias. "Changes in University Students' Aids-related Knowledge, Attitudes and Behaviours, 1988 and 1992." Canadian Journal of Public Health 84.4 (July/August 1993): 275-78. Ac cessed February 28, 2016. http://www.jstor.org/stable/41991035.

Robinson, Laura. “Condoms cont.” The Mustang Daily. California Polytechnic State University. November 3, 1987. Accessed February 28, 2016. http://goo.g1/9mCimw.

San Luis Obispo County Public Health Department AIDS Program. “Epidemiological Profile HIV/AIDS in San Luis Obispo County, CA.”June 2007. Accessed February 28, 2016. http://goo.gl/G6XHkU.

Shilts, Randy. And the Band Played On. New York: St. Martin's Press, 1987.

Shupe, Renee. "AIDS: Deadly Disease Threatens More Than Homosexuals." The Mustang Daily. California Polytechnic State University. October 24, 1985. Accessed February 28, 2016.http://goo.g1/jgZdZM.

“A 'Terrifying' Disease: AIDS And its Many Victims.” The Mustang Daily. California Polytechnic State University. October 24, 1985. Accessed February 28, 2016. http://goo.gl/jgZdZM.

Stewart, Elise. "The Restroom is for Condoms." The Mustang Daily. California Polytechnic State University. November 3, 1987. Accessed February 28, 2016. http://goo.gl/9mCimw.

United States Department of Health and Human Services: AIDS. "A Timeline of HIV/AIDS.” 2015. Accessed February 28, 2016. http://www.aids.gov/hiv-aids-ba sics/hiv-aids-101/aids-timeline/.

. "Global Statistics." 2015. Accessed February 28, 2016. http://www.aids.gov/ hiv-aids-basics/hiv-aids-101/aids-timeline/.

Vance, Carol J. “AIDS: The Modern Plague.” The Mustang Daily. California Polytechnic State University. May 8, 1984. Accessed February 28, 2016. http://goo.gl/yU9150. 
.AIDS to be Part of Books, Classes." The Mustang Daily. California

Polytechnic State University. April 9, 1987. Accessed February 28, 2016. http://goo.gl/sYHPYj.

Yoshitake, Dawn. "AIDS: A Disease Carrying Common Misconceptions." The Mustang Daily. California Polytechnic State University. April 12, 1985. Accessed February 28, 2016. http://goo.gl/SNGsSU. 